\title{
Specify Site If Distant Metastasis Submitted
}

National Cancer Institute

\section{Source}

National Cancer Institute. Specify Site If Distant Metastasis Submitted. NCI Thesaurus.

Code C159721.

A request to specify the site if distant metastasis was submitted. 